\title{
Rapid Quantitative Detection by Real-Time Polymerase Chain Reaction with a Polymer Chip
}

\author{
Yoshinori Akagi, Kazuhiko Imamura, Takamasa Kouno, Shigeru Nomura, \\ Shuji Kage, Mitsuyoshi Ema ${ }^{1}$, Naoki Nishijima ${ }^{1}$, Kazuki Yamamoto², \\ Toshiro Migita ${ }^{3}$ and Futoshi Shibasaki ${ }^{3, *}$ \\ Sekisui Chemical Co., Ltd., \\ 2-1 Hyakuyama, Shimamoto-cho, Mishima-gun, Osaka 618-0021, Japan \\ 'Pulstec Industrial Co., Ltd., \\ 35-7000 Nakagawa, Hosoe-cho, Kita-ku, Hamamatsu-shi, Shizuoka 431-1304, Japan \\ ${ }^{2}$ Sekisui Integrated Research Inc., \\ 2-2 Kamityoushi-cho, Kamitoba, Minami-ku, Kyoto-shi, Kyoto 618-8105, Japan \\ ${ }^{3}$ Department of Molecular Medical Research, Tokyo Metropolitan Institute of Medical Science, \\ 2-1-6 Kamikitazawa, Setagaya-ku, Tokyo 156-8506, Japan
}

(Received February 24, 2015; accepted April 13, 2015)

Key words: PCR, DNA amplification, array chip, polymer chip, rapid PCR

The conventional real-time polymerase chain reaction (PCR) used in clinical settings is slow $(>1 \mathrm{~h})$. We describe the development of a real-time PCR system for the rapid, high sensitivity detection of infectious diseases. We have improved the polymer-based PCR chip and thermal control unit. A polymer with high thermal diffusivity, thermal conductivity, and glass transition temperature was used for the PCR chip. The thermal control unit consisted of a denaturing block, an annealing/extension block, and a cooling block set at $20^{\circ} \mathrm{C}$. The heating and cooling rates were 7.2 and $-14.2{ }^{\circ} \mathrm{C} / \mathrm{s}$, respectively. The cooling rate was 10 times higher with the cooling block than without the cooling block. Using this rapid real-time PCR system, we sucessfully detected mycoplasma genomic deoxyribonucleic acid with a detection limit of $6.0 \times 10^{-5} \mathrm{ng} / \mu \mathrm{L}$ in $8.5 \mathrm{~min}$.

\section{Introduction}

The polymerase chain reaction (PCR) is used to amplify a specific gene or a region of deoxyribonucleic acid (DNA). ${ }^{(1)}$ The technique is widely used in hospitals and inspection centers to diagnose various infectious diseases, including mycoplasma pneumonia, ${ }^{(2)}$ human papilloma virus, ${ }^{(3)}$ and influenza virus. ${ }^{(4)}$ The simple, fast detection

"Corresponding author: e-mail: shibasaki-ft@igakuken.or.jp 
of microorganisms that cause infectious diseases allows doctors to treat patients quickly. However, the conventional PCR used in hospitals takes more than $1 \mathrm{~h}$ because the instruments use a temperature-controlled metal block to perform more than 30 thermal cycles, and each cycle takes $2-3$ min.

Recently, micro-fabrication technology has led to the development of a variety of PCR and DNA analysis devices, for example, high-throughput capillary array electrophoresis microplates, ${ }^{(5)}$ integrated PCR-capillary electrophoresis microchips, ${ }^{(6)}$ and a miniaturized portable device for single nucleotide polymorphism detection. ${ }^{(7)}$

To achieve rapid PCR, the thermal mass of the system is reduced to increase the heating rate during temperature cycling. However, a small mass or volume does not necessarily contribute to fast PCR thermal cycling. ${ }^{(8)}$ Kopp et al. reported continuousflow PCR in 1987. ${ }^{(9)}$ Continuous-flow PCR equipment contains three temperature zones for denaturing, annealing, and extension, and the PCR reagents flow through each temperature zone. Kopp et al. performed 20 cycles of amplification in $90 \mathrm{~s}$ using a glass microfluidic device. However, because each target requires three temperature zones (denaturing, annealing, and extension zones), it is difficult to measure several targets on a microfluidic device.

Microchamber array PCR can detect a number of targets simultaneously on a silicon chip. ${ }^{(10-13)}$ The array of microfabricated silicon reaction chambers can analyze samples of 5 to 500 bacterial cells by PCR in 7 min with a thermal cycle time of $17 \mathrm{~s} .{ }^{(10)}$ However, silicon chip devices are expensive and difficult to dispose of safely.

Polymer-based microfabricated devices are being developed as an alternative to silicon- and glass-based devices. A polymer-based PCR device requires high heat resistance, low water absorbance, and excellent optical properties. Polymer-based PCR chips fabricated from polydimethylsiloxane (PDMS) ${ }^{(14)}$ and polyimide ${ }^{(15)}$ that use external heating elements for thermal cycling have been developed.

Various methods of adhesion for the polymers, including hot embossing, ${ }^{(16,17)}$ the adhesive tape bonding of PDMS, ${ }^{(18)}$ and the use of cross-linking adhesives, have been reported. ${ }^{(19)}$ In the adhesion of cross-linking silicone rubber (CSR), ${ }^{(20)}$ the silicone rubber couples to a silane compound and adheres to the polymer chip, and the surface is activated by corona discharge. CSR is a high-strength adhesive, whose thickness can easily be controlled. It causes the minimal deformation of the microchannels because it does not require heat, unlike hot embossing. It is a good adhesive for different polymers with various glass transition temperatures $\left(T_{\mathrm{g}}\right)$.

In this paper, we report a rapid real-time PCR system coupled with a thermal unit assembly consisting of a denaturing heating block, an annealing-extension heating block, and a cooling block for cooling between denaturing and annealing. We confirm that our system is suitable for diagnosing infectious diseases by performing PCR on mycoplasma genomic DNA. This system enables the rapid, sensitive, and efficient amplification of DNA on a polymer-based array chip. 


\section{Materials and Methods}

\subsection{PCR chip preparation}

A 12-chamber pattern was formed on a polycarbonate (PC) substrate (Panlite, Teijin Ltd., Japan) with magnets 50 (wide) $\times 50$ (long) $\times 1$ (thick) $\mathrm{mm}^{3}$ [Fig. 1(a)]. The dimensions of each chamber were $6.9 \times 2 \times 1 \mathrm{~mm}^{3}$ [Fig. 1(b)]. The PCR chip consisted of a PC microchannel layer and cyclo-olefin polymer (COP) film (ZF16, Zeon Corp., Japan) layers with CSR adhesive (Asahi Rubber Inc., Japan) [Fig. 1(c)].

\subsection{Genomic DNA and primer}

Mycoplasma genitalium genomic DNA was obtained from ATCC (BAA-2641-SD, USA). The primers were custom-synthesized by Hokkaido System Science Co., Ltd. (Japan). The sequences of the primers were as follows: forward primer, 5'-TAC ATG CAA GTC GAT CGG AAG TAG C-3'; reverse primer, 5'-AAA CTC CAG CCA TTG CCT GCT AG-3'.

\subsection{PCR reactions}

Part of the 16S RNA fragment was amplified by PCR. PCR was performed in 20 $\mu \mathrm{L}$ of the reaction mixture containing $0.06 \mathrm{ng} / \mu \mathrm{L}$ genomic DNA, $0.5 \mu \mathrm{M}$ each of the primers, $10 \mathrm{mM}$ Tris- $\mathrm{HCl}$ ( $\mathrm{pH} 8.3$ ), $50 \mathrm{mM} \mathrm{KCl}, 1.5 \mathrm{mM} \mathrm{MgCl}, 0.2 \mathrm{mM}$ dNPT, 1.25 U of Takara Taq First detect (Takara Bio Inc., Japan), and 1/10,000 diluted SYBR Green I (Lonza, Switzerland). PCR conditions were: hot-start process, $98{ }^{\circ} \mathrm{C}$ for $15 \mathrm{~s}$; 30 cycles of denaturation, $101{ }^{\circ} \mathrm{C}$ for $1 \mathrm{~s}$; and annealing and extension, $65{ }^{\circ} \mathrm{C}$ for $1 \mathrm{~s}$.

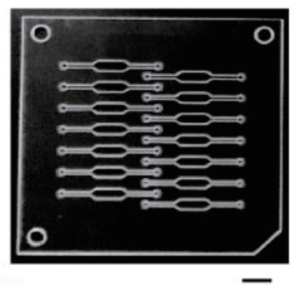

(a)

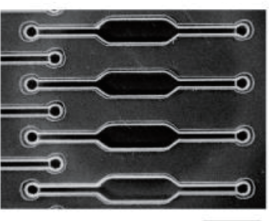

(b)

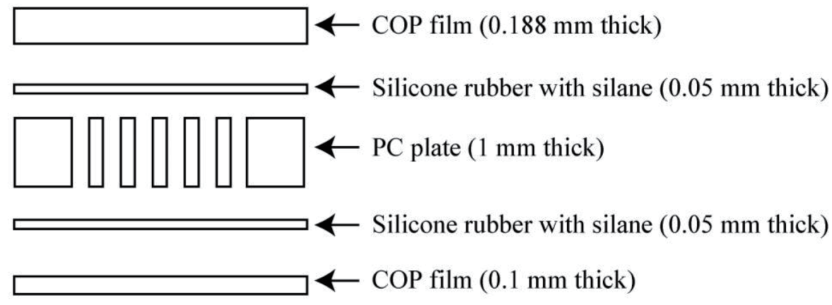

(c)

Fig. 1. (a) Photograph of the array-based PCR chip. (b) Magnified image of the array-based PCR chip. (c) Schematic of the layers of the PCR chip. Silicone rubber is used as the adhesion layer. The scale bar is $0.5 \mathrm{~mm}$. 
These temperatures were measured on the surfaces of the heating and cooling blocks with a thermocouple (ST-50-300, RKC Instrument Inc., Japan). PCR performance was evaluated by electrophoresis. DNA was separated on $2 \%$ agarose gel containing ethidium bromide at $100 \mathrm{~V}$ for $20 \mathrm{~min}$.

\subsection{Measurement of glass transition temperature $\left(T_{\mathrm{g}}\right)$}

$T_{\mathrm{g}}$ was measured by thermogravimetric differential scanning calorimetry and differential thermal analysis (EXSTAR 6000, SII, Japan) at a ramp rate of $10{ }^{\circ} \mathrm{C} / \mathrm{min}$ from 20 to $300{ }^{\circ} \mathrm{C}$. The $T_{\mathrm{g}}$ values of COP (ZF16, Zeon Corp., Japan), PC (Panlite, Teijin Ltd., Japan), and polymethyl methacrylate (PMMA; Acrylite, Mitsubishi Rayon Co., Ltd., Japan) were determined.

\section{Results and Discussion}

\subsection{Rapid real-time PCR system and PCR array chip}

Our rapid real-time PCR system consisted of two heating blocks for denaturing and annealing-extension, a cooling block for cooling between denaturing and annealing, a charge-coupled device (CCD) camera for detecting fluorescence intensity, and a computer for controlling the system [Fig. 2(a)]. Figure 2(b) shows the heating or cooling step for the PCR chip. In the first step, each block is kept at a constant temperature in its original position; the denaturing block is at $101{ }^{\circ} \mathrm{C}$, the annealing-extension block is at $65^{\circ} \mathrm{C}$, and the cooling block is at $20^{\circ} \mathrm{C}$. In the second step, the denaturing block was turned under the PCR chip. In the third step, the denaturing block was raised to contact the PCR chip. The PCR reaction was performed on the PCR chip by repeating these three steps.

Thermal diffusivity $(\alpha)$ is given by eq. (1), where $\lambda$ is the thermal conductivity, $\rho$ is the density, and $C_{\mathrm{p}}$ is the specific heat capacity. ${ }^{(21,22)}$

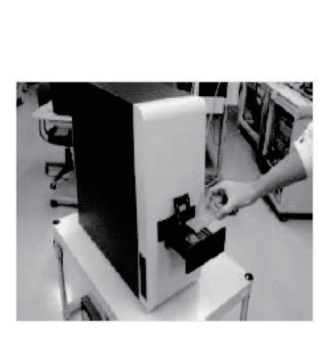

(a)

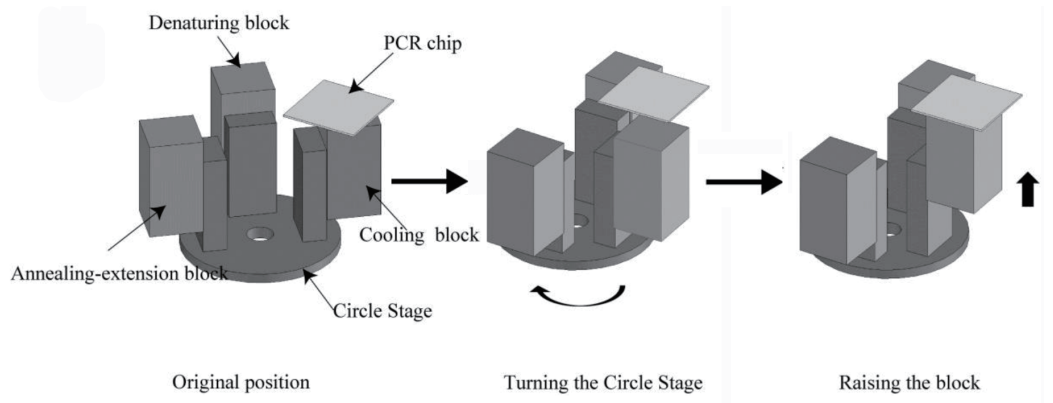

(b)

Fig. 2. (a) Photograph of the rapid real-time PCR system. (b) Schematic of the temperature control unit and its operation. 


$$
\alpha=\frac{\lambda}{\rho \cdot C_{\mathrm{p}}}
$$

Table 1 shows the thermal characteristics (thermal diffusivity, thermal conductivity, and $T_{\mathrm{g}}$ ) of COP, PMMA, and PC. The thermal diffusivities of COP, PMMA, and PC are $0.10,0.072$, and 0.11 , respectively. Thermal diffusivity is a material-specific property for characterizing unsteady heat conduction; it describes how quickly a material reacts to a change in temperature. Thus, COP and PC heat more rapidly than PMMA. The $T_{\mathrm{g}}$ values of COP, PMMA, and $\mathrm{PC}$ are 170,90 , and $150{ }^{\circ} \mathrm{C}$, respectively. During denaturing, the microchambers on the PCR chip must not deform above $95^{\circ} \mathrm{C}$. COP and $\mathrm{PC}$ both have good heat resistance. Furthermore, the autofluorescence of COP is not detected by the CCD camera in our PCR system. Because PC is 4 times more expensive than COP, our PCR chip consists of a bottom layer of COP film, a 1-mm-thick core layer of PC with microchannels, and a top layer of COP film [Fig. 1(b)].

\subsection{Thermal control of rapid real-time PCR}

The thermal cycle profile of our rapid real-time PCR system is shown in Fig. 3. Figure 3(a) shows the cooling profiles from denaturing to annealing-extension with and without the cooling block. A cooling rate of $-14.2{ }^{\circ} \mathrm{C} / \mathrm{s}$ was obtained with the cooling block, whereas without the cooling block, the cooling rate was $-1.4^{\circ} \mathrm{C} / \mathrm{s}$, which was 10 times lower.

Table 1

Thermal characteristics of COP, PMMA, and PC.

\begin{tabular}{lccc}
\hline Polymer & COP & PMMA & PC \\
\hline Thermal diffusivity $\left(\mathrm{mm}^{2} / \mathrm{s}\right)$ & 0.10 & 0.072 & 0.11 \\
Thermal conductivity $(\mathrm{w} / \mathrm{mK})$ & $0.16^{(23)}$ & $0.25^{(22)}$ & $0.19^{(22)}$ \\
Glass transition temperature $\left({ }^{\circ} \mathrm{C}\right)$ & 170 & 90 & 150 \\
\hline
\end{tabular}

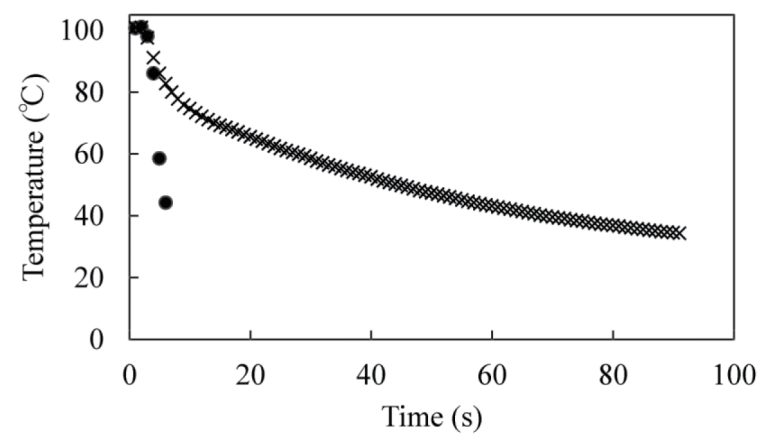

Fig. 3. Cooling profiles of array-based PCR chips with $(\bullet)$ and without $(\times)$ the cooling block at $20^{\circ} \mathrm{C}$. The contact time with the cooling block is $0.5 \mathrm{~s}$ and the thermocouple sampling time is $1 \mathrm{~s}$. 
Figure 4 shows a PCR cycle with the heating and cooling blocks that gives fast changes in temperature. Our PCR system uses the hot-start process and completes 30 PCR cycles in $8.5 \mathrm{~min}$. In Fig. 4(b), the transition time from 101 to $45{ }^{\circ} \mathrm{C}$ including undershoot time is just under $5 \mathrm{~s}$, recovery to $65^{\circ} \mathrm{C}$ takes $3 \mathrm{~s}$, and the transition time from 65 to $101{ }^{\circ} \mathrm{C}$ is $6 \mathrm{~s}$. The maximum heating and cooling rates are 7.2 and $-14.2{ }^{\circ} \mathrm{C} / \mathrm{s}$, respectively. The maximum cooling rate was twice the maximum heating rate. The rapid thermal cycling takes $16 \mathrm{~s} /$ cycle; previous rapid PCR techniques on silicon chips took $30^{(24-26)}$ and $17 \mathrm{~s} /$ cycle. ${ }^{(10)}$ The short cycle times were achieved by having a small thermal mass and decreasing the PCR dwell times. Dwell times of 1-5 s have been used for the melting and annealing steps, and a temperature ramp rate of $4{ }^{\circ} \mathrm{C} / \mathrm{s}$ has been achieved for cooling ${ }^{(26)}$ and a temperature ramp rate of $6^{(10)}$ or $30^{\circ} \mathrm{C} / \mathrm{s}^{(25)}$ for heating (Table 2). Our rapid real-time PCR achieved a short cycle time comparable to silicon-based chips by using our thermal control method, even though the thermal properties of the polymerbased chip are inferior to those of silicon.

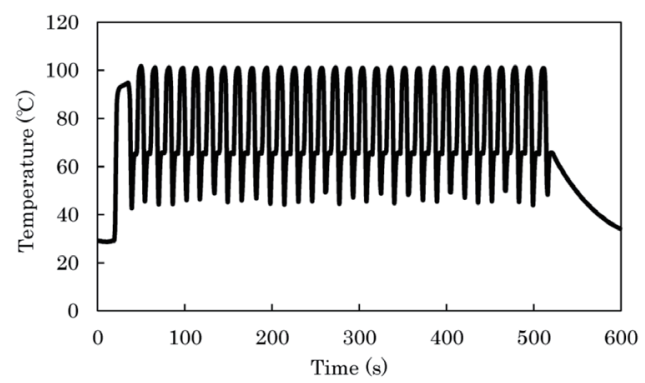

(a)

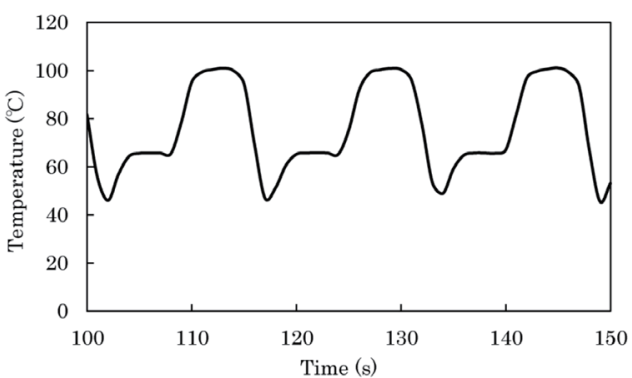

(b)

Fig. 4. (a) Temperature profile of rapid real-time PCR with the hot-start process. The temperature is measured with a thermocouple under the array-based PCR chip. (b) Magnification of (a) from 100 to $150 \mathrm{~s}$.

Table 2

PCR performance between our rapid real-time PCR system and previously reported microchipbased PCR system.

\begin{tabular}{lccc}
\hline Reference & Material & Heating rate $\left({ }^{\circ} \mathrm{C} / \mathrm{s}\right)$ & Cooling rate $\left({ }^{\circ} \mathrm{C} / \mathrm{s}\right)$ \\
\hline This system & COP & 7.2 & 14.2 \\
10 & Silicon & 6.5 & 4.3 \\
14 & PDMS & 2.0 & 1.2 \\
15 & Polymide & 10 & 10 \\
25 & Polypropylene & 30 & 4 \\
26 & Quartz glass & 4 & 4 \\
\hline
\end{tabular}




\subsection{Evaluation of rapid real-time PCR system}

The rapid real-time PCR system was evaluated with mycoplasma genomic DNA $\left(6.0 \times 10^{-2} \mathrm{ng} / \mu \mathrm{L}\right)$. A series of 10-fold dilutions of the genomic DNA from $6.0 \times 10^{-2}$ to $6.0 \times 10^{-5} \mathrm{ng} / \mu \mathrm{L}$ were prepared. Figure $5(\mathrm{a})$ shows that for concentrations of $6.0 \times$ $10^{-2}, 6.0 \times 10^{-3}, 6.0 \times 10^{-4}$, and $6.0 \times 10^{-5} \mathrm{ng} / \mu \mathrm{L}$ to the PCR reagents, the fluorescence intensity increased after 22, 27, 32, and 39 cycles, respectively. The results of the gel electrophoresis of these PCR products are shown in Fig. 5(b). A 402 bp band was observed for each concentration of PCR product.

The correlation between the genomic DNA dilution and the threshold cycle $\left(C_{t}\right)$ value was analyzed by plotting a standard curve (Fig. 6). A linear regression relationship was

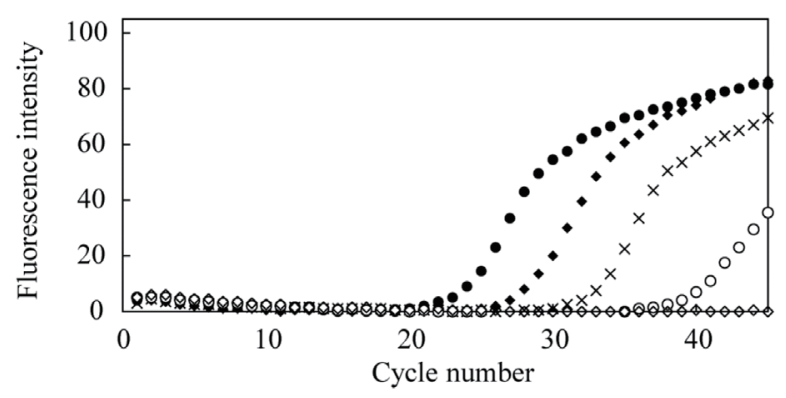

(a)

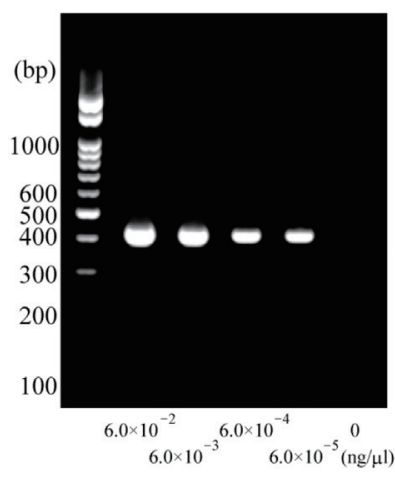

(b)

Fig. 5 (a) Fluorescence intensity as a function of cycle number for rapid real-time PCR for mycoplasma genomic DNA concentrations of $6.0 \times 10^{-2}(\bullet), 6.0 \times 10^{-3}(\bullet), 6.0 \times 10^{-4}(\times), 6.0 \times 10^{-5}(\circ)$, and $0 \mathrm{ng} / \mu \mathrm{L}(\diamond)$. (b) Photograph of gel electrophoresis results for the PCR products.

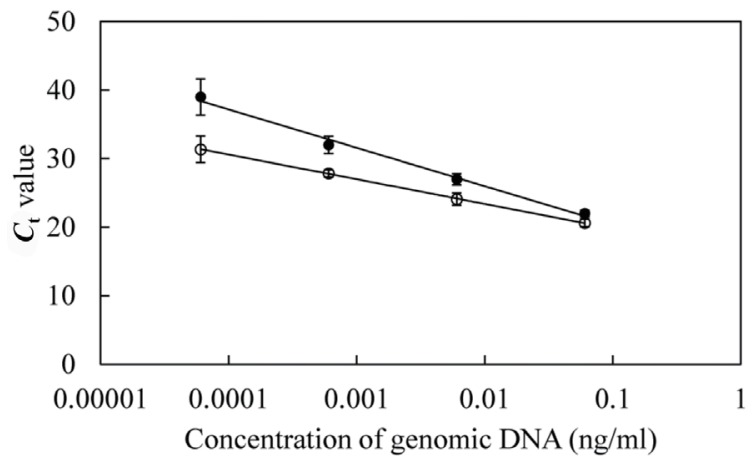

Fig. 6. $C_{\mathrm{t}}$ as a function of the concentration of mycoplasma genomic DNA. The symbols of and $\circ$ indicate our rapid real-time PCR and conventional real-time PCR, respectively. Error bars indicate $\mathrm{SD}(n=3)$. 
observed with a determination coefficient (R2) of 0.992 , a slope of -3.73 , a reaction efficiency of $85.4 \%$, a standard deviation (SD) from 0.5 to 1.2 , and a relative standard deviation (RSD) from 2.1 to 6.1\%. Conventional real-time PCR (Thermal cycler 96, Roche Diagnostics K.K., Switzerland) for mycoplasma genomic DNA under the same conditions with a detection time limit of $1 \mathrm{~h}$ had a detection limit of $6.0 \times 10^{-5} \mathrm{ng} / \mu \mathrm{L}$, a slope of -3.59 , a reaction efficiency of $89.9 \%$, a SD from 1.8 to 5.5, and a RSD from 1.8 to $5.5 \%$. This demonstrates that our rapid real-time PCR achieved high sensitivity and precision with a detection speed 7 times higher than that of conventional real-time PCR.

\section{Conclusions}

In this report, we have described a rapid real-time PCR system with a polymer-based chip. The array-based PCR chip was made of COP and PC, both of which have excellent thermal diffusivity, thermal conductivity, and $T_{\mathrm{g}}$. The thermal unit consisted of two heating blocks and one cooling block. The heating and cooling rates were 7.2 and -14.2 ${ }^{\circ} \mathrm{C} / \mathrm{s}$, respectively. The cooling rate with the cooling block was 10 times higher than that without the cooling block. An increase in fluorescence was confirmed with the polymerbased PCR chip. Mycoplasma genomic DNA was detected with our real-time PCR, and the detection limit was $6.0 \times 10^{-5} \mathrm{ng} / \mu \mathrm{L}$, which is similar to that for conventional realtime PCR. Furthermore, 30 cycles of PCR were completed in 8.5 min including the hot-start process. The rapid and sensitive detection of mycoplasma genomic DNA was accomplished with our thermal control method and polymer-based PCR chip.

\section{Acknowledgements}

We acknowledge T. Takano, K. Nomura, and K. Shimamura of Asahi Rubber Inc. for the fabrication of the PCR chip by CSR, T. Uehara and M. Uehara of Shoei Kousakusyo Co., Ltd. for chip molding, Y. Fujii, T. Tomaru, H. Yamauchi, S. Matsumoto, and T. Ohmura of Sekisui Chemical Co., Ltd. for discussion and support, and Tokyo Biomarker Innovation Research Association for financial support of this work.

\section{References}

1 K. R. Saiki, S. Scharf, F. Faloona, K. B. Mullis, G. T. Horn, H. A. Erlich and N. Arnheim: Science 230 (1985) 1350.

2 T. N. Canavan, E. F. Mathes, I. Frieden and K. Shinkai: J. Am. Acad. Dermatol. 72 (2015) 239.

3 M. Onuki, K. Matsumoto, T. Satoh, A. Oki, S. Okada, T. Minaguchi, H. Ochi, S. Nakao, K. Someya, H.Yamada, H. Hamada and H. Yoshikawa: Cancer Sci. 100 (2009) 1312.

4 A.Sakurai and F. Shibasaki: Viruses 4 (2012), 1235.

5 P. C. Simpson, D. Roach, A. T. Woolley, T. Thorsen, R. Johnston, G. F. Sensabaugh and R. A. Mathies: Proc. Natl. Acad. Sci. U.S.A. 95 (1998) 2256.

6 W. C. Dunn, S. C. Jacobson, L. C. Waters, N. Kroutchinina, J. Khandurina, R. S. Foote, M. J. Justice, L. J. Stubbs and J. M. Ramsey: Anal. Biochem. 27 (2000) 157.

7 Y. Akagi, M. Makimura, Y. Yokoyama, M. Fukazawa, S. Fujiki, M. Kadosaki and K. Tanino: Electrochim. Acta 51 (2006) 6367. 
8 M. G. Roper, C. J. Easley and J. P. Landers: Anal. Chem. 77 (2005) 3887.

9 M. U. Kopp, A. J. de Melb and A. Manz: Science 280 (1998) 1046.

10 P. Belgrader, W. Benett, D. Hadley, J. Richards, P. Stratton, R. Mariella, Jr. and F. Milanovich: Science 284 (1999) 449.

11 H. Nagai, Y. Murakami, Y. Morita, K. Yokoyama and E. Tamiya: Anal. Chem. 73 (2001) 1043.

12 Y. Matsubara, K. Kerman, M. Kobayashi, S. Yamamura, Y. Morita and E. Tamiya: Biosens. Bioelectron. 20 (2005) 1482.

13 Y. Matsubara, K. Kerman, M. Kobayashi, S. Yamamura, Y. Morita, Y. Takamura and E. Tamiya: Anal. Chem. 76 (2004) 6434.

14 Y. S. Shin, K. Cho, S. H. Lim, S. Chung, S.-J. Park, C. Chung, D.-C. Han and J. K. Chang: J. Micromech. Microeng. 13 (2003) 768.

15 B. C. Giordano, J. Ferrance, S. Swedberg, A. F. R. Hühmer and P. Landers: Anal. Biochem. 291 (2001) 124.

16 R. Novak, N. Ranu and R. A. Mathies: Lab Chip 13 (2013) 1468.

17 Y. Luo, X. Wang and Y. Yang: J. Mater. Process. Technol. 208 (2008) 63.

18 C. S. Thompson and A. R. Abate: Lab Chip 13 (2013) 632.

19 J. B. You, K. I. Min, B. Lee, D. P. Kim and S. G. Im: Lab Chip 13 (2013) 1266.

20 K. Takagi, H. Hirahara, K. Mori, E. Narita, Y. Oishi and K. Mori: Nippon Gomu Kyokai Tokyo 81 (2008) 18.

21 P. Lohe: Kolloid Z. Z. Polym. 204 (1965) 7.

22 K. Mitani: Syasyutsu Seikei Kanagata (Shiguma Shuppan, 1997).

23 Springer Handbook of Condensed Matter and Materials Data, ed. M. Werner and W. Hands (Springer, Germany, 2005) pp. 487-490.

24 P. C. Simpson, D. Roach, A. T. Wooley, T. Thorsen, R. Johnston, G. F. Sensabaugh and R. A. Mathies: Proc. Natl. Acad. Sci. U.S.A. 95 (1998) 2256.

25 M. A. Northrup, B. Benett, D. Hadley, P. Landre, S. Lehew, J. Richards and P. Stratton: Anal. Chem. 70 (1998) 918.

26 T. Taylor, E. Winn-Dean, E. Picozza, T. Woudenberg and M. Albin: Nucleic Acids Res. 25 (1997) 3164. 